Lisa Sachs is the Director of the Columbia Center on Sustainable Investment at Columbia University, where she oversees CCSI's robust research portfolio on Mining \& Energy; Land, Agriculture \& Food Systems; Investment Law \& Policy; and Sustainable Finance. She teaches at Columbia Law School and Columbia's School of International and Public Affairs, and at Externado University in Bogotá, Colombia. She received a Bachelor of Arts in Economics from Harvard University, and earned her Juris Doctor and a master's degree in international affairs from Columbia University, where she was a James Kent Scholar and recipient of the Parker School Certificate in International and Comparative Law.

Jeffrey David Sachs is known as one of the world's leading experts on economic development and the fight against poverty. He is the former director of the Earth Institute at Columbia University and is currently the Quetelet Professor of Sustainable Development at Columbia's School of International and Public Affairs and a professor of health policy and management at Columbia's School of Public Health. He also serves as special adviser to the United Nations Secretary-General António Guterres on the Sustainable Development Goals (SDGs), and as Director of UN Sustainable Development Solutions Network. Sachs has written several books and received many awards.

\title{
9. Health Priorities for Sustainable Development
}

\section{Lisa E. Sachs and Jeffrey D. Sachs}

\section{Introduction ${ }^{1}$}

The right to health has been repeatedly recognized as one of the core human rights. Good health is so essential for human functioning, human dignity, economic well-being, and development that the achievement of good health is among the highest goals of international and national policies, and one of the highest commitments assumed by Member States within the United Nations (UN) and its various bodies. Three of the eight Millennium Development Goals (MDGs) adopted for 2000-2015 were focused on health (Goal 4 on child survival, Goal 5 on maternal health, and Goal 6 on disease control). Sustainable Development Goal 3 (to "ensure healthy lives and promote well-being for all at all ages") for the period 2015-2030 is even more expansive, not only including the three MDG goals but also calling for Universal Health Coverage (SDG Target 3.8) among other objectives. ${ }^{2}$ Health is also deeply implicated in most of the other 16 SDGs, especially those relating to poverty and hunger, inequalities, water and

\footnotetext{
${ }^{1}$ This Chapter was initially written well before the COVID-19 pandemic; it has been updated in October 2020 for publication. The authors are grateful to Shannon Marcoux for her invaluable assistance in updating the chapter. ${ }^{2}$ General Assembly Resolution 70/1, Transforming our world: the 2030 Agenda for Sustainable Development, A/RES/70/1 (25 September 2015.
} 
sanitation, decent work, human settlements, education, gender equality, environmental sustainability, climate change, marine resources, terrestrial ecosystems, and global partnership. ${ }^{3}$

The COVID-19 pandemic has, of course, put public health and healthcare into the forefront of policy and daily life as perhaps never before in modern times, and certainly to an extent unprecedented since the Flu epidemic of 1918-19. The pandemic has not only been a human tragedy and upheaval, but also another vivid proof of just how far we are from realizing the universal right to health. Once again, we are seeing the disease burden fall disproportionately on poor and vulnerable populations. Not only has the pandemic so far killed well over 1 million people as of October 2020, with confirmed infections of more than 40 million, but it has devastated national economies, raised extreme poverty and hunger by hundreds of millions of people, and set back the SDGs by many years.

By any reasonable standard, the right to health eludes hundreds of millions and with COVID-19, perhaps billions of people. The most serious deficiencies are in poor countries, but are also in middle-income and even rich countries, notably the United States, which has the worst health coverage among the high-income countries. Even countries in Western Europe, renowned for their health coverage and high life expectancy, have done a very poor job in containing the COVID-19 pandemic.

There are several factors that account for the gross international disparities in health outcomes. From an epidemiological point of view, the excess disease burdens in low-income settings relate mainly to the high burden of disease associated with three main conditions: infectious diseases (such as AIDS, TB, malaria and now COVID-19), nutritional deficiencies, and maternal and perinatal conditions. ${ }^{4}$ In turn, the challenges of rampant infection, chronic malnutrition, and unsafe childbirth relate to several underlying factors, including unsafe drinking water leading to water-borne diseases, unsafe living conditions, chronic infections, and lack of access to health facilities for prevention and treatment, to name a few. These conditions in turn depend upon socioeconomic, political and environmental factors, including: the levels of income of households, the community, and the nation; the policies and expenditures of government at all

\footnotetext{
${ }^{3}$ For the content and background of the SDGs, see id. For a recent assessment of progress in realizing the SDGs, see United Nations, The Sustainable Development Goals Report 2020, (2020), https:/unstats.un.org/sdgs/report/2020/The-Sustainable-Development-Goals-Report-2020.pdf.

${ }^{4}$ Max Roser and Hannah Ritchie "Burden of Disease," Our World in Data (OurWorldInData.org, 2020), https://ourworldindata.org/burden-of-disease.
} 
levels; the education, incomes, and behaviour patterns of individual households; the ecological conditions that affect the transmission of diseases (such as worms and malaria) and access to safe water; the vulnerability of the region to natural hazards, such as droughts, floods, and extreme storms; the productivity of local agriculture; and the transport costs and trade policies regarding foodstuffs and other critical inputs for health. The challenges and outcomes of the 17 Sustainable Development Goals are therefore inherently inter-linked; achieving the goals related to health requires policy interventions across many of the other goals and targets as well. ${ }^{5}$

COVID-19 has also made vivid the shortfalls in public health and healthcare in the rich countries as well, most notably the United States, which has the most unequal access to health care of any of the high-income countries in the OECD. Though the rich countries were purportedly the most prepared of all countries in the world to deal with a public health emergency, in practice, the rich countries of North America (Canada and the US) and many of the countries of Europe performed very poorly in containing the pandemic during 2020. These countries lacked effective systems of disease surveillance, testing, contact tracing, and quarantining that are paramount in epidemic control, and the governments lacked the confidence and backing of the general public needed to implement key behavioural changes.

\section{The poverty-disease trap of low-income countries}

Since 2000, economists have increasingly emphasized the centrality of health to economic wellbeing, tracing the linkages from improved health outcomes to economic growth and development, and also working with epidemiologists to identify the most effective ways to invest in improved health. The Commission on Macroeconomics and Health of the World Health Organization (2000-1) found that improved health powerfully raised living standards of the population and promoted economic growth through several channels, including the accumulation of human capital (education, skills, and physical health over the lifecycle) and a faster demographic transition to lower fertility rates, resulting in greater increases in output per capita. ${ }^{6}$

\footnotetext{
${ }^{5}$ Sachs, J.D., Schmidt-Traub, G., Mazzucato, M. et al. Six Transformations to achieve the Sustainable Development Goals. Nat Sustain 2, 805-814 (2019). https://doi.org/10.1038/s41893-019-0352-9.

${ }^{6}$ WHO Commission on Macroeconomics and Health [chaired by Jeffrey Sachs], Macroeconomics and Health: Investing in Health for Economic Development, Geneva: World Health Organization, 20 December 2001. ("WHO, Investing in Health"), http://whqlibdoc.who.int/publications/2001/924154550x.pdf.
} 
Importantly, however, the reverse is also true: the main overarching risk factor for poor health is poverty, a fact proved in a multitude of ways, including comparisons across societies and across socioeconomic groups within societies. One compelling illustration of the impact of poverty on health is the low life expectancy in the poorest countries. While high-income countries have a life expectancy at birth of nearly 80 years, least-developed countries have a global average of 60 years. ${ }^{7}$ Similar discrepancies exist on other broad measures, such as infant mortality and mortality of children under age 5 .

Many policy makers have now appropriately recognized the poverty-disease nexus as a "poverty trap:" economic development and ample financial resources are required to alleviate the poverty-related burdens of poor health, low literacy, and resource depletion, yet economic development is blocked by precisely these poverty-related burdens, which decrease productivity, earning ability, and economic investments. Poor communities lack both basic infrastructure and the means to ensure access to health interventions, and remain poor as a result. Poor nations are unable to fund health systems at all levels. They are also generally more vulnerable to diseases in part because of the disproportionate geographic burden of infectious diseases in tropical countries. Yet unhealthy people, in turn, are burdened by low economic productivity - due to chronic physical ailments, absenteeism, under-schooling (e.g., disease-related dropouts) and long-term cognitive and physical disabilities - which prevent them from generating the income and public tax revenues required to tackle the underlying causes of poor health.

The implications of a poverty-disease trap (and of a poverty-human capital trap more generally) are profound. They suggest that poor countries on their own are unable to realize the human rights to health and education, the constituents of human capital vital for skill development and active labor force participation and labor productivity. Improved health and education require increased public outlays and infrastructure that are beyond the financial means of the poor countries themselves. Yet without improved health and education, economic progress itself is put in jeopardy. The only way to break the vicious circle of poverty and low human capital (health and education) may be to intervene from the outside, for example, through development aid that is directed at improving the health and educational attainment of the low-

\footnotetext{
${ }^{7}$ World Bank, Life expectancy at birth, total (years): http://data.worldbank.org/indicator/SP.DYN.LE00.IN/countries/1W?display=graph. High-income countries represented here by an average of OECD Countries.
} 
income population. Of course, international development aid is probably best directed not only at ameliorating poor health and education but at ending all aspects of the poverty trap, including: low human capital, poor infrastructure, poor governance, and environmental vulnerability.

Building on the work of the Commission on Macroeconomics and Health in 2000-1, the World Health Organization (WHO) has continued to put a price tag on international investment in health systems. The WHO Health Financing Working Paper No. 1 found that a rudimentary healthcare system in a low-income country would require US\$86 per capita as of 2015 (in 2012 US dollar terns). ${ }^{8}$ Another report from WHO found that the bottom 10 countries in terms of per capita health spending were able to muster only around US\$30 per person per year, requiring international assistance to make up the difference. ${ }^{9}$

More recently, the IMF has studied the financing gap facing 57 Low-Income Developing Countries (LIDC) in achieving the SDGs. ${ }^{10}$ The IMF's careful methodology was the following. For five of the key SDG categories - health, education, roads, electricity, and water and sanitation - the IMF estimated the public-sector outlays required to achieve the 2030 SDG targets, and then considered the potential domestic budget revenues available to fund these outlays. The Fund recognized that the LIDCs would have to increase their domestic resource mobilization through higher tax collections, but that there would be practical and economic limits in doing so. As a result, the Fund determined that there is an intrinsic SDG financing gap between what the countries need to spend on SDG objectives and what they can fund domestically out of public revenues. The gap, notes the Fund, will have to be filled through international development assistance or some related means (such as global tax reforms that increase the ability to raise domestic revenues).

According to the IMF's calculations, meeting the SDGs requires an increase in outlays of around \$528 billion as of 2030 (in \$US 2016 prices), but increased domestic revenues can cover only around $\$ 170$ billion per year, leaving an SDG financing gap of around \$358 billion. Notably, this amounts to only around 0.3 percent of GDP, or around 0.7 percent of the GDP of

\footnotetext{
${ }^{8}$ Jowett M, Brunal MP, Flores G, Cylus J. Spending targets for health: no magic number. Geneva: World Health Organization; 2016 (WHO/HIS/HGF/HFWorkingPaper/16.1; Health Financing Working Paper No. 1); http://apps.who.int/iris/bitstream/10665/250048/1/WHO-HIS-HGF- HFWorkingPaper-16.1-eng.pdf.

${ }^{9} \mathrm{Xu}$ K, Soucat A \& Kutzin J et al. Public Spending on Health: A Closer Look at Global Trends. Geneva: World Health Organization; 2018 (WHO/HIS/HGF/HFWorkingPaper/18.3). Licence: CC BY-NC-SA 3.0 IGO.

${ }^{10}$ Vitor Gaspar, et al., "Fiscal Policy and Development: Human, Social, and Physical Investment for the SDGs," IMF Staff Discussion Note 19/03, January 2019.
} 
the donor countries. While the IMF did not allocate the gap across sectors, we can estimate that of the $\$ 358$ billion annual gap, health coverage may account for around $\$ 50$ billion per year, on the order of 0.1 percent of the GDP of the high-income OECD countries. Note of course that these estimates did not anticipate the added costs of fighting the COVID-19 pandemic (both the direct health costs and also the more general economic costs and losses to government budgets).

Although this chapter heavily focuses on the international disparities, and the yawning gaps in health achievement in the lower-income countries, the Coronavirus pandemic has underscored how poverty also impinges on health at the household and local community level. The Coronavirus has disproportionately impacted disadvantaged and marginalized populations within high-income countries, both in terms of infection rates and outcomes. Groups particularly affected include the elderly, particularly those in residential care facilities, and populations with pre-existing health risks exacerbated by poverty, poor nutrition, and disproportionately poor health services. Workers in the service industry, which are predominantly lower-paying jobs with fewer benefits including healthcare benefits, protective equipment, paid sick leave, and job protections, remain most vulnerable to both transmission and poorer outcomes. ${ }^{11}$ The international right to health discussed throughout this Chapter applies as vigorously to the poorer and vulnerable populations within high-income countries as well, with corresponding implications for necessary policies, investments and financing.

\section{The SDG Context (SDG 3)}

For the period 2016-2030, the globally agreed targets for health are contained in SDG 3, which calls on all countries to "ensure healthy lives and promote wellbeing for all at all ages." The specific targets are described in Box 1. These are enormously ambitious goals, as they call for all countries to achieve minimum acceptable standards on maternal mortality, newborn mortality, and under-5 mortality, as well as the end of the AIDS, TB, malaria, and neglected tropical disease epidemics, dramatic reductions of non-communicable diseases, and universal access to healthcare, among other targets. While these objectives are technically within reach, they would require a significant scale-up of public investments in most developing countries, and a

\footnotetext{
${ }^{11}$ Committee on Economic, Social and Cultural Rights, Statement on the coronavirus disease (COVID-19)
} pandemic and economic, social and cultural rights (E/C.12/2020/1). 
significant annual transfer of funds from the high-income donor nations to the low-income developing countries to finance the increased outlays, on the order of $\$ 50$ billion per year.

Box 1. SDG 3 Targets

3.1 By 2030, reduce the global maternal mortality ratio to less than 70 per 100000 live births. 3.2 By 2030, end preventable deaths of newborns and children under 5 years of age, with all countries aiming to reduce neonatal mortality to at least as low as 12 per 1000 live births and under-5 mortality to at least as low as 25 per 1000 live births.

3.3 By 2030, end the epidemics of AIDS, tuberculosis, malaria and neglected tropical diseases and combat hepatitis, water-borne diseases and other communicable diseases.

3.4 By 2030, reduce by one third premature mortality from non-communicable diseases through prevention and treatment and promote mental health and well-being.

3.5 Strengthen the prevention and treatment of substance abuse, including narcotic drug abuse and harmful use of alcohol.

3.6 By 2020, halve the number of global deaths and injuries from road traffic accidents.

3.7 By 2030, ensure universal access to sexual and reproductive health-care services, including for family planning, information and education, and the integration of reproductive health into national strategies and programmes.

3.8 Achieve universal health coverage, including financial risk protection, access to quality essential health-care services and access to safe, effective, quality and affordable essential medicines and vaccines for all.

3.9 By 2030, substantially reduce the number of deaths and illnesses from hazardous chemicals and air, water and soil pollution and contamination.

3.a Strengthen the implementation of the WHO Framework Convention on Tobacco Control in all countries, as appropriate.

3.b Support the research and development of vaccines and medicines for the communicable and non-communicable diseases that primarily affect developing countries, provide access to affordable essential medicines and vaccines, in accordance with the Doha Declaration on the TRIPS Agreement and Public Health, which affirms the right of developing countries to use to the full the provisions in the Agreement on Trade-Related Aspects of Intellectual Property Rights 
regarding flexibilities to protect public health, and, in particular, provide access to medicines for all.

3.c Substantially increase health financing and the recruitment, development, training and retention of the health workforce in developing countries, especially in least developed countries and small island developing States.

3.d Strengthen the capacity of all countries, in particular developing countries, for early warning, risk reduction and management of national and global health risks.

\section{Global cooperation to realize the human right to health}

The two-way nexus between poverty and health has been widely recognized by United Nations bodies, other intergovernmental organizations, governments, and academics, which have placed a price tag on the needed assistance. Yet despite this broad understanding of the vicious cycle of poverty and disease - and international capacity to break that cycle - the international community has mustered only a laggard and insufficient response to the poverty-disease trap. We thus find ourselves in a dangerous and unjustifiable predicament: the countries that bear the disproportionate burden of disease have the least capacity to do anything about it, yet the countries with sufficient means have been derelict in making available the necessary resources to improve health outside their own countries. ${ }^{12}$ Ironically, in addition to neglecting their commitments to alleviate poverty and disease in low-income countries, rich countries are also putting themselves at risk; as the Coronavirus, like several other viruses in recent years, has shown us, many infectious diseases do not respect country borders and can easily spread from continent to continent. For this reason, one scholar wisely and presciently noted that "safeguarding the world's population requires cooperation and global governance."13

Despite earlier steps to promote global cooperation on issues of health and poverty, like the Global Fund to Fight AIDS, TB, and Malaria of the Global Alliance for Vaccines and Immunizations launched in 2002, official development assistance (ODA) for health as a percentage of total ODA has failed to increase over the last decade-13.1\% in 2009 and $13.0 \%$ in 2018 - while total volume of health ODA has increased only modestly during

\footnotetext{
${ }^{12}$ Lawrence O. Gostin, “A Proposal for a Framework Convention on Global Health,” Journal of International Economic Law 10(4) (2007): 989-1008.

${ }^{13}$ Ibid., 989.
} 
the past decade - peaking at $\$ 24.4$ billion in 2017 before falling to $\$ 22.2$ billion the following year. ${ }^{14}$ This annual flow is perhaps $\$ 30$ billion per year less than needed to achieve the SDGs in a typical year, with an even greater gap when we add the costs of COVID-19 control. Realizing the right to health therefore requires a system of increased financial transfers and proper management systems to ensure that international resources reliably and accountably reach those in need. Human rights, economic development, and public management merge at this point, requiring a new and effective form of cooperation among human rights advocates, public health specialists, public health economists, and public-sector managers.

\section{The right to health under international law}

In addition to the economic imperative to invest in the right to health (and the moral imperative to prevent unnecessary disease and deaths), there is also a legal imperative grounded in binding international legal instruments, wherein States have undertaken to realize specific human rights, including through "international assistance and cooperation." ${ }^{15}$ The universal right to health was one of the fundamental human rights envisioned by the nascent intergovernmental organizations in the mid-twentieth century and has been embodied in numerous intergovernmental treaties, declarations and resolutions. ${ }^{16}$ Indeed, every country in the world is party to at least one international convention or treaty that includes the affirmation of health rights and imposes obligations relevant to achieving the right to heath. ${ }^{17}$

At the formation of the UN in 1945, one of the first intergovernmental organizations envisioned to supplement the mandate and authority of the UN was a global health

\footnotetext{
${ }^{14}$ Duncan Knox, “Aid spent on health: ODA data on donors, sectors, recipients," Development Initiatives, July 2020, https://devinit.org/resources/aid-spent-health-oda-data-donors-sectors-recipients/\#section-1-2.

${ }^{15}$ UN General Assembly, International Covenant on Economic, Social and Cultural Rights (ICESCR), UN General Assembly Resolution 2200A (XXI), 16 December 1966, https://www.ohchr.org/en/professionalinterest/pages/cescr.aspx, Article 2(1); UN Charter arts. 1(3), 55, 56; UDHR art. 22; Convention on the Rights of the Child, opened for signature Nov. 20, 1989, arts. 4, 24(4), 144 U.N.T.S. 123, (entered into force Sept. 2, 1990). See also Octovio Ferraz and Judith Bueno de Mesquita, "The Right to Health and the Millennium Development Goals in Developing Countries: A right to International Assistance and Cooperation?" Right to Health Unit, Human Rights Centre, University of Essex, July 2006, http://repository.essex.ac.uk/9786/1/right-to-health-millenium-development-goals-developing-countries.pdf.

${ }^{16}$ Stephen P. Marks, "Emergence and Scope of the Right to Health," in José M. Zuniga, Stephen P. Marks and Lawrence O. Gostin (eds.), Advancing the Human Right to Health, Oxford University Press, 2013, pp. 3-23

${ }^{17}$ P.C. Kuszler, "Global Health and the Human Rights Imperative," Asian Journal of WTO \& International Health Law and Policy, vol. 2, 2007, 99.
} 
organization. ${ }^{18}$ Less than three years after the UN Charter came into force, the WHO was formed, and its constitution came into force on April 7, 1948. ${ }^{19}$ According to the WHO constitution, "the enjoyment of the highest attainable standard of health is one of the fundamental rights of every human being without distinction of race, religion, political belief, economic or social condition," 20 and the mission of the WHO is "the attainment by all peoples of the highest possible level of health." 21 The WHO has the power to adopt conventions (Article 19), promulgate binding regulations (Article 21), make recommendations (Article 23), and monitor the national health legislation (Article 63) of its Member States.

The first two of these powers are quite important. The WHO, by a two-thirds vote, can adopt binding conventions or regulations, which Member States are affirmatively required to submit to their national legislative bodies for ratification, and to notify the Director-General of the action the State has taken within eighteen months. If the national legislature does not ratify an adopted convention, the State must report its reasons to the Director-General (Article 20). Similarly, all adopted regulations are binding on Member States unless the State specifically rejects the regulation (Article 22). In general, all members of the WHO have an obligation to adopt measures and legislation that are consistent with the stated goals and declarations of the WHO and not to adopt any measures that directly contravene any of these goals. Despite its extraordinary legislative powers, the WHO has been reluctant to create binding norms that could help achieve international cooperation on the universal right to health. The WHO has only adopted four binding legal instruments: the 1967 Nomenclature Regulations, two instruments related to tobacco production - one in 2003 and one in 2013 - and the International Health Regulations (IHR). The IHR date back to 1951, but as of 1995, the treaty only applied to cholera, the plague, and yellow fever. ${ }^{22}$ While calls for reform emerged in the mid-1990s, the SARS epidemic in China in the early 2000s catalyzed the major overhaul of the International Health Regulations in $2005 .^{23}$

\footnotetext{
${ }^{18}$ World Health Organization, "Global Health Histories: Origin and development of health cooperation," https://www.who.int/global_health_histories/background/en/.

${ }^{19}$ Ibid.

${ }^{20}$ Constitution of the World Health Organization, opened for signature 22 July 1946, 62 Stat. 6279, 14 UNTS 185, preamble.

${ }^{21}$ Ibid.

${ }^{22}$ Ibid.

${ }^{23}$ Ibid., 267.
} 
The International Health Regulations (IHR) of 2005, which came into force in 2007, legally bind 196 States Parties to certain rights and obligations "to prevent, protect against, control and provide a public health response to the international spread of disease." 24 While previous versions of the IHR were disease-specific in nature, the scope of the 2005 IHR included health issues related to biological, chemical, and radionuclear events. ${ }^{25}$ The IHR obligate States Parties to collaborate with one another to develop and maintain core capacities and infrastructure to detect, prevent, contain and report threats to health before they cross international borders. ${ }^{26}$ The IHR also include the Director-General's exclusive power to declare and to terminate a public health emergency of international concern (PHEIC) and to provide temporary, non-binding recommendations for States Parties to take in light of the emergency situation. ${ }^{27}$ The DirectorGeneral declared a PHEIC in 2009 for the H1N1 influenza pandemic, which was met with criticism and laxity from States. After this pandemic, in 2011, the WHO Review Committee responsible for evaluating the IHR implementation and WHO response to the H1N1 pandemic warned that " $[\mathrm{t}]$ he world is ill-prepared to respond to a severe influenza pandemic or to any similarly global, sustained and threatening public-health emergency." ${ }^{28}$ In 2014, the Director General declared two different PHEICs, for Ebola and polio, and then in 2016 the Director General declared the fourth ever PHEIC for the Zika pandemic. ${ }^{29}$ On January 30, 2020, the Director-General of the WHO convened the IHR Emergency Committee, declared the COVID19 outbreak a PHEIC and issued corresponding temporary recommendations. ${ }^{30}$

The Universal Declaration of Human Rights (UDHR), adopted in 1948, reaffirms the right to health in the context of the right to an adequate standard of living (Article 25 (1)). The UDHR is not a treaty and therefore is not legally binding on the Member States of the UN, but "unlike many subsequent declarations, the UDHR "enjoys a more elevated status, largely

\footnotetext{
${ }^{24}$ World Health Organization, "States Parties to the International Health Regulations (2005)," https://www.who.int/ihr/legal_issues/states_parties/en/; WHO, International Health Regulations, art 2. (2005), https://www.who.int/publications/i/item/9789241580496.

${ }^{25}$ Lawrence O. Gostin, Mary C DeBartolo, and Erin A. Friedman, "The International Health Regulations 10 years on: the governing framework for global health security," The Lancet 386 (2015): 2222-26, 2222.

${ }^{26}$ Ibid.

${ }^{27}$ Lawrence O. Gostin and Rebecca Katz, "The International Health Regulations: The Governing Framework for Global Health Security" (2016). Georgetown Law Faculty Publications and Other Works. 1770. https://scholarship.law.georgetown.edu/facpub/1770, 273.

${ }^{28}$ Ibid.

${ }^{29}$ Ibid., 273-74.

${ }^{30}$ World Health Organization, "Timeline of WHO's response to COVID-19”, https://www.who.int/news/item/2906-2020-covidtimeline.
} 
because of its foundational role and universal acceptance,"31 and it can be used "as an interpretative instrument and can give rise to customary law." ${ }^{32}$ Unlike the UDHR, the International Covenant on Economic, Social and Cultural Rights (ICESCR) is legally binding on States that sign and ratify it, although States are then allowed to demur from specific articles of the Covenant through reservations, by restricting their obligations under the treaty. The core provision on the international right to health is Article 12 of the ICESCR, which recognizes "the right of everyone to the enjoyment of the highest attainable standard of physical and mental health. [Steps required] include those necessary for...the prevention, treatment and control of epidemic, endemic, occupational and other diseases [and]...the creation of conditions which would assure to all medical service and medical attention in the event of sickness." ${ }^{33}$

The formal content and scope of the right to health has been further clarified through a series of UN documents, especially General Comments issued by the Committee on Economic, Social and Cultural Rights (CESCR). The CESCR is responsible for the promotion, interpretation and implementation of the ICESCR, and from time to time issues General Comments that attempt to clarify the scope of the rights and obligations of the State Parties with respect to the various articles and provisions of the ICESCR. These General Comments are not binding on the parties, but they nevertheless are "recognised as having significant legal weight and offering jurisprudential insights into the rights enumerated in the ICESCR." ${ }^{34}$

In May 2000, the CESCR adopted General Comment No. 14 on the "Right to the Highest Attainable Standard of Health." ${ }^{35}$ The Comment specified that while the right to health certainly includes the right to equal and timely access to health services, it also requires States Parties to ensure the underlying determinants of health, including safe drinking water, essential medicines, essential food, basic shelter, and sanitation. Furthermore, the Comment recognized that universal

\footnotetext{
${ }^{31}$ Kuszler, "Global Health and the Human Rights Imperative," supra, note 17

${ }^{32}$ Ferraz and Mesquita, "The Right to Health and the Millennium Development Goals," supra, note 15.

${ }^{33}$ ICESCR, supra, note 15, Article 12. Several non-binding WHO and UN General Assembly resolutions and international agreements have reaffirmed the international commitment to the right to health. For instance, the Alma-Ata Declaration, adopted in 1978 at the International Conference on Primary Health Care in Alma-Ata, Kazakhstan, convened by the WHO and the United Nations Children's Fund (UNICEF) reaffirmed that health is a "fundamental human right" and called for all countries to "cooperate in a spirit of partnership and service to ensure primary health care for all people since the attainment of health by people in any one country directly concerns and benefits every other country." WHO, Declaration of Alma-Ata, Alma-Ata, International Conference on Primary Health Care, USSR, 6-12 September, 1978, https://www.who.int/publications/almaata_declaration_en.pdf ${ }^{34}$ Ferraz and Mesquita, "The Right to Health and the Millennium Development Goals," 9, supra, note 15. ${ }^{35}$ Committee on Economic, Social and Cultural Rights, General Comment No. 14: The Right to the Highest Attainable Standard of Health (Art. 12), UN Doc. E/C.12/2000/4, adopted 11 August 2000.
} 
access to essential medicines is a core, non-derogable duty of all Member States, as is preventing, treating, and controlling epidemic and endemic diseases. ${ }^{36}$

Article 15(1)(b) of the ICESCR also states that everyone has the right "to enjoy the benefits of scientific progress and its applications." ${ }^{37}$ This right is significant in light of the disproportionate disease burden in developing countries, the immense disparities in access to essential medicines across the globe, and the inequitable number of medicines designed for developing-country health needs. In 2001, the CESCR adopted a General Statement on "Human Rights and Intellectual Property" that makes clear that the right to enjoy the benefits of scientific progress - including medication — must be respected in the realm of international trade; and any intellectual property regime must include provisions for protecting public health. ${ }^{38}$ Four years later, the Committee consolidated its position on intellectual property and human rights in its General Comment No. 17 wherein it stated that States have a duty to balance these interests in a way that prevents unreasonably high costs for medication. ${ }^{39}$ In April 2020, the committee reiterated the obligation of states to adapt intellectual property regimes "to allow universal access to the benefits of scientific advances relating to COVID-19 such as diagnostics, medicines and vaccines." 40

As a result, in large part, of the work of the Special Rapporteur in the field of cultural rights, ${ }^{41}$ the CESCR adopted a General Comment in 2020 on the right to science, which the Committee defines as "not only a right to receive the benefits of the applications of scientific progress, but also a right to participate in scientific progress. ${ }^{42}$ This General Comment No. 25

\footnotetext{
${ }^{36}$ Ibid. at para. 43(d) and 44(c). On access to medicines as a component of the right to health, see Stephen P. Marks, "Access to Essential Medicines as a Component of the Right to Health," in A. Clapham and M. Robinson (eds), Realizing the Right to Health, Swiss Human Rights Book Series. Zurich: Rüfer \& Rub, 2009, pp. 82-101.

${ }^{37}$ ICESCR, supra, note 15, Article 15.

${ }^{38}$ Committee on Economic, Social and Cultural Rights, Follow-up to the day of general discussion on article 15.1 (c), Monday, 26 November 2001. Human rights and intellectual property. Statement by the Committee on Economic Social and Cultural Rights, UN Doc. E/C.12/2001/15 (2001), 14 December 2001, para. 2.

${ }^{39}$ Committee on Economic, Social and Cultural Rights, General Comment No. 17 (2005). The right of everyone to benefit from the protection of the moral and material interests resulting from any scientific, literary or artistic production of which he or she is the author (article 15, paragraph 1 (c), of the Covenant), UN Doc. E/C.12/GC/17, 12 January 2006, para. 35.

${ }^{40}$ Committee on Economic, Social and Cultural Rights, Statement on the coronavirus disease (COVID-19) pandemic and economic, social and cultural rights, UN Doc. (E/C.12/2020/1), 6 April 2020, para. 21.

${ }^{41}$ Human Rights Council, Report of the Special Rapporteur in the field of cultural rights, Farida Shaheed. The right to enjoy the benefits of scientific progress and its applications, UN Doc. A/HRC/20/26, 14 May 2012, para. 75 (b).

${ }^{42}$ Committee on Economic, Social and Cultural Rights, General comment No. 25 (2020) on science and economic, social and cultural rights (article 15 (1) (b), (2), (3) and (4) of the International Covenant on Economic, Social and Cultural Rights), UN Doc. E/C.12/GC/25, 30 April 2020, para. 11.
} 
addresses health in several important ways. It defines as one of the core obligations of this right that States Parties "[e]nsure that in the allocation of public resources, priority is given to research in areas where there is the greatest need for scientific progress in health, food and other basic needs." ${ }^{43}$ It also addresses, as it did in General Comment No. 17, ${ }^{44}$ the need to balance incentives for the development of new products with access to health in light of the inaccessibility of products and technologies when priced out of reach for low-income persons or developing countries. ${ }^{45}$ The critical need for new discoveries to prevent and treat COVID-19 makes the recommendations of the Committee all the more urgent, such as calling on States "to counter distortions of funding associated with intellectual property, [by providing] adequate financial support for research ... either through national efforts or, if necessary, by resorting to international and technical cooperation." 46

\section{Responsibilities of donor nations to support health in low-income countries}

Despite the universal recognition of the right to health as a basic human right, international law is ill-equipped to protect and promote this right adequately, especially in the developing world where the need is greatest. Traditional international human rights law is premised on States having the primary obligation to protect and promote the human rights of the citizens within their jurisdiction; thus, governments have the obligation to realize the right to health of their own citizens. In low income countries, where governments do not have the resources to achieve the universal right to health as envisioned in United Nations agreements, the right to health should be "progressively" achieved, according to available resources. This means that citizens of developing countries have different "highest attainable standards" of health than do citizens of rich countries: ${ }^{47}$

Each State Party to the present Covenant undertakes to take steps, individually and through international assistance and cooperation, especially economic and technical, to the maximum of its available resources, with a view to achieving progressively the full

\footnotetext{
43 Ibid., para. 52.

${ }^{44}$ General Comment No. 17, supra, note 39.

${ }^{45}$ General Comment No. 25, supra, note 42, para. 61.

${ }^{46}$ Ibid., para. 62.

${ }^{47}$ Barbara C. Alexander, "Lack of Access to HIV/AIDS Drugs in Developing Countries: Is There a Violation of the International Human Right to Health?, Human Rights Brief 12: 8 No. 3 (2001): 13.
} 
realization of the rights recognized in the present Covenant by appropriate means, including particularly the adoption of legislative measures. ${ }^{48}$

As noted in other chapters in this publication, the italicized words reflect the acknowledgement in a legal instrument of the pragmatic approach favoured by economists based on the fundamental reality of scarcity of resources. This approach overlooks two critical points from an economic perspective. First, as already discussed, poor countries are marred in health crises precisely because they do not have the resources to improve all aspects of a health system, including clean drinking water, trained medical personnel, essential medicines and equipment, health education, and other basic health fundamentals. Moreover, a healthy population is a key component of economic development. When countries are caught in an extreme poverty trap, it is illogical and impractical to insist that poor populations await the "progressive realization" of their right to health, subject to the available resources of their government. Furthermore, the focus on the right to health obligations of poor countries to their own populations overlooks the legally binding obligations of third-party States to assist with the realization of the right to health in resource-poor countries. The latter point is the focus of this section.

Again, from an economic perspective, prior to the COVID-19 pandemic, a transfer of just 0.1 per cent of rich States' annual income would close the financing gap for realizing the right to health in poor countries. It is a question of helping poor countries to reduce their resource constraints to allow them to meet the health needs of their populations. But importantly, the economics of financial transfers to realize the right to health is again backed by international law. The overarching obligation of all UN Member States to cooperate for the achievement of human rights is articulated in the UN Charter. Specifically, the Charter states that the purposes of the $\mathrm{UN}$ are to "achieve international co-operation in solving international problems of an economic, social, cultural or humanitarian character." 49 Articles 55 and 56 call for UN Member States to take "joint and separate action in co-operation with the Organisation" to achieve the purposes of the UN, which include "higher standards of living, full employment, and conditions of economic and social progress and development."50

\footnotetext{
${ }^{48}$ Ibid. Article 2. Emphasis added.

${ }^{49}$ UN Charter Article 1, para. 3.

${ }^{50}$ UN Charter Article 55, 56.
} 
In 1990 the ICESCR referred to international assistance and cooperation in General Comment 3 , stating in particular that:

in accordance with Articles 55 and 56 of the Charter of the United Nations, with wellestablished principles of international law, and with the provisions of the Covenant itself, international cooperation for development and thus for the realization of economic, social and cultural rights is an obligation of all States. It is particularly incumbent upon those States which are in a position to assist others in this regard. ${ }^{51}$

This obligation to assist in achieving the right to health for persons not within the jurisdiction of a given State Party is further reinforced by the obligation, contained in the Vienna Convention on the Law of Treaties, of States that are signatories but not parties to a treaty such as the ICESCR "to refrain from acts that would contravene the object and purpose" of the treaty until or unless the State makes it clear that it does not intend to become a party to the treaty. ${ }^{52}$ Moreover, States that are neither parties nor signatories to the ICESCR, including the United States, still assume "general obligations not to contravene UN resolutions in this regard, as members of the United Nations." 53

Several UN resolutions and declarations have affirmed the Member States' commitment to international assistance, including in relation to access to medicines. The Millennium Declaration, adopted by the General Assembly in 2000, recognized "a collective responsibility to uphold the principles of human dignity, equality and equity at the global level." 54 Developed countries agreed to undertake concrete actions such as the adoption of fair trade rules, debt relief programmes for heavily indebted poor countries, and increased development assistance to poor countries committed to poverty reduction. Several of the targets of SDG3 ("Ensure healthy lives and promote well-being for all at all ages"), commit states to such assistance with respect to the right to health, including to "[s] upport the research and development of vaccines and medicines for the communicable and non-communicable diseases that primarily affect developing

\footnotetext{
${ }^{51}$ Committee on Economic, Social and Cultural Rights, General Comment 3: The Nature of States Parties Obligations (Art. 2, para. 1), U.N. Doc. E/1991/23, adopted on 14 December 1990, para. 14.

52 Vienna Convention on the Law of Treaties, 23 May, 1969, 1155 U.N.T.S. 331, Article 18.

53 Alicia Ely Yamin, "Not Just A Tragedy: Access to Medications as a Right Under International Law," B.U. Int'1 L.J., 21 (2003):325-399,

${ }^{54}$ General Assembly Resolution 55/2. "United Nations Millennium Declaration,” adopted 8 September 2000 , para. 2.
} 
countries, provide access to affordable essential medicines and vaccine ....and, in particular, provide access to medicines for all" (3.b); to "[s]ubstantially increase health financing and the recruitment, development, training and retention of the health workforce in developing countries, especially in least developed countries and small island developing States" (3.c); and to "[s]trengthen the capacity of all countries, in particular developing countries, for early warning, risk reduction and management of national and global health risks." $(3 . \mathrm{d})^{55}$ While these SDGs are important guiding principles on the right to health, the UN Special Rapporteur on the Right to Health recognized that "weak accountability requirements, unclear guidance on how to implement the Sustainable Development Goals holistically and a failure to make commitments or offer guidance on how to transform the global financial system to support such a broad and ambitions global strategy" undermine their effective implementation. ${ }^{56}$

Indeed, the commitments States made by adopting the SDGs echo their legally binding obligation to assist and cooperate with the realization of the right to health in impoverished countries based on the language of the UN Charter and the specific language of the ICESCR, including the interpretive comments of the CESCR. However, the lack of specific measures that States should take to fulfil their legal obligations under the ICESCR and political commitments under the SDGs have rendered these obligations unenforceable. The General Comments have taken some steps to articulate the meaning of third-party State obligations. According to the Comments, the CESCR envisions that third-party States have the same tripartite responsibilities as those of States Parties to their own citizens: to respect, to protect and to fulfil all economic and social rights referred to in the ICESCR. The third-party State obligation to respect human rights in other countries and "to refrain from interfering with the realization of economic, social and cultural rights in other countries" is the least contentious aspect of the third-party State obligations and is generally understood to be the "minimum obligation." ${ }^{57}$ For instance, General Comment No.14 on the Right to Health states that all State Parties must "respect the enjoyment of the right to health in other countries." 58

\footnotetext{
${ }^{55}$ SDG Target 3.B, Ibid.

${ }^{56} \mathrm{UN}$ General Assembly, Note by the Special Rapporteur on the right of everyone to the enjoyment of the highest attainable standard of physical and mental health, UN doc. A/71/304, 5 August 2016, para. 9.

${ }^{57}$ Wouter Vandenhole, "A Partnership for Development: International Human Rights Law as an Assessment Instrument," Submission to the 2nd Session of the UN High-Level Task Force on the Right to Development (2005), para. 9. http://www2.ohchr.org/english/issues/development/docs/vandenhole.doc.

${ }^{58}$ CESCR, General Comment 14, supra, note 35, para. 39.
} 
However, the General Comments clearly indicate that the ICESCR envisions the obligations of third-party States as going beyond the minimum of "respecting" rights in other countries. General Comment No. 14 states that States Parties must also "prevent third parties from violating the right [to health] in other countries, if they are able to influence these third parties by way of legal or political means, in accordance with the Charter of the United Nations and applicable international law." 59 The third-party State obligation to protect the realization of human rights in all countries from the interference of third parties under its control has not yet been conceptualized or enforced in practice, yet much has been written about the importance of this obligation to "protect." For instance, with respect to access to medicines, many have argued that States Party to the ICESCR have a binding obligation to regulate the activity of pharmaceutical companies that are incorporated within their State; accordingly, States would violate the right to health under the ICESCR "by failing to influence pharmaceutical corporations' actions that restrict access to HIV/AIDS drugs in developing countries."

In a report on the international health worker skills drain, the former Special Rapporteur on the right to health, Paul Hunt, stated that, in accordance with the obligation to protect the right to health in third countries, "developed countries should ensure that their human resource policies do not jeopardize the right to health in developing countries." 61 He offered the following example:

If a developed country actively recruits health professionals from a developing country that is suffering from a shortage of health professionals in such a manner that the recruitment reduces the developing country's capacity to fulfill the right to health obligations that it owes its citizens, the developed country is prima facie in breach of its human rights responsibility of international assistance and cooperation in the context of the right to health. ${ }^{62}$

Hunt carried the concept of the obligation to protect further by drafting and submitting to the General Assembly a set of "Human Rights Guidelines for Pharmaceutical Companies in

\footnotetext{
${ }^{59}$ Ibid.

${ }^{60}$ Alexander, "Lack of Access to HIV/AIDS Drugs," supra, note 47, 12.

${ }^{61}$ UN General Assembly, The right of everyone to the enjoyment of the highest attainable standard of physical and mental health. Note by the Secretary General, UN Doc. A/60/348, 12 September 2005, para. 61

62 Ibid.
} 
Relation to Access to Medicines." 63 The obligation to protect also requires third-party States that are concluding international or regional agreements on any issue to ensure that these instruments - such as bilateral or multilateral trade and investment agreements - do not adversely impact the realization of the right to health in other countries; and states that are members of international organizations, such as the World Bank, the WTO, and the IMF, are obligated to influence the lending policies, credit agreements, and other international policies of these institutions so that they are consistent with the objectives of the ICESCR. ${ }^{64}$

The final obligation - that to fulfil - is the most difficult of all the obligations to conceptualize and to make operational. As one scholar noted, "any suggestion of a legal obligation to provide development aid [...] has invariably been met by hesitation or rejection from even the most generous donor countries." ${ }^{65}$ Nevertheless, the General Comments clearly envision aid - both financial and technical - to be an obligation of countries with available resources for the realization of rights in poor countries. General Comment No.14 states that "[d]epending on the availability of resources, States should facilitate access to essential health facilities, goods and services in other countries, wherever possible and provide the necessary aid when required." 66 In addition to General Comment No. 14, other General Comments to the ICESCR have enumerated specific obligations of third-party States to assist with the realization of rights in developing countries, including the right to adequate housing, ${ }^{67}$ the right to education, ${ }^{68}$ the right to food, ${ }^{69}$ and the right to water. ${ }^{70}$ As the same scholar noted, despite the existence of these third-party extraterritorial obligations to assist with the realization of human rights in other countries, the obligations "to protect" and "to fulfil" are "still part of the law 'under construction,' that is the law as it ought to be."'71

\footnotetext{
${ }^{63}$ UN General Assembly, Report of the Special Rapporteur on the right of everyone to the enjoyment of the highest attainable standard of physical and mental health, UN doc. A/63/263, 11 August 2008, Annex.

${ }^{64}$ CESCR, General Comment 14, supra, note 35, para. 39; Committee on Economic, Social and Cultural Rights, GC No. 15, The right to water (arts. 11 and 12), UN Doc. E/C.12/2002/11 20 January 2003, para. 36.

${ }^{65}$ Vandenhole, "A Partnership for Development," supra, note 57, para. 9.

${ }^{66}$ CESCR, General Comment 14, supra, note 35, para. 39

${ }^{67}$ CESCR, General Comment 4, The right to adequate housing (Art. 11 (1) of the Covenant), UN Doc. E/1992/23, 13 December 1991, para. 19.

${ }^{68}$ CESCR, General Comment No. 13: The Right to Education (Art. 13 of the Covenant), 8 December 1999, E/C.12/1999/10.

${ }^{69}$ CESCR, The right to adequate food (Art.11), General comment 12, UN Doc. E/C.12/1999/5, 12 May 1999.

${ }^{70} \mathrm{CESCR}$, The right to water (arts. 11 and 12 of the Covenant), General Comment 15, UN Doc. E/C.12/2002/11, 20 January 2003.

${ }^{71}$ Vandenhole, “A Partnership for Development," supra, note 57, para. 9.
} 
The emphasis here on the obligations of developed countries is not intended to minimize the role that governments of poor countries have in the realization of the right to health and other basic human rights in their own countries. Third-party extraterritorial obligations are complementary to domestic State obligations. ${ }^{72}$ Poor governance, discrimination, corruption, and warped ideology are unfortunate realities and impediments to the right to health in many countries, developing and developed alike. Efforts to improve governance, accountability, equitable distribution and access systems, and social justice are necessary but not sufficient to achieving the universal right to health. The point stressed here is that poverty remains the most critical obstacle to the realization of the right to health in developing countries and has only increased as a result of COVID-19. Indeed, in its statement on COVID-19, the Committee on Economic, Social and Culture Rights noted that health-care programs "have been weakened by decades of underinvestment in public health services and other social programmes, accelerated by the global financial crisis of 2007-2008. Consequently, they are ill equipped to respond effectively and expeditiously to the intensity of the current pandemic." 73 The Statement continues that the global crisis "highlights the crucial importance of international assistance and cooperation," noting that the "needs of vulnerable and disadvantaged groups as well as fragile

\footnotetext{
${ }^{72}$ Although this chapter does not discuss the specific obligations of non-State parties, the role of non-State actors in assisting or restricting the realization of the right to health in developing countries should not be understated. The crucial role and responsibilities of international organizations, such as the World Bank and the IMF, and the business sector, specifically the pharmaceutical industry, in the promotion and protection of the right to health has increasingly been discussed by governments, civil society and scholars. General Comment No. 14 also emphasizes that the private business sector has responsibilities regarding the realization of the right to health, and there are increasingly examples of domestic legal systems where legislation has been used to challenge pharmaceutical companies' restrictive policies, often based on competition, marketing or patent laws. The specific obligations and responsibilities of international business organizations are addressed in the Guiding Principles on Business and Human Rights (GP), contained in the Report the Special Representative of the Secretary-General on human rights and transnational corporations and other business enterprises, (UN Doc. A/HRC/17/31, 21 March 2011, Annex) and endorsed by the Human Rights Council in its Resolution 17/4 of 16 June 2011. On the application of these GP to the pharmaceutical industry, see Joo-Young Lee and Paul Hunt, "Human Rights Responsibilities of Pharmaceutical Companies in Relation to Access to Medicines," The Journal of Law Medicine \& Ethics 40(2)( 2012):220-33; Suerie Moon, "Respecting the right to access to medicines: Implications of the UN Guiding Principles on Business and Human Rights for the pharmaceutical industry," Health and Human Rights 15/1 (2013), https://www.hhrjournal.org/2013/10/respecting-the-right-to-access-to-medicines-implications-of-the-un-guidingprinciples-on-business-and-human-rights-for-the-pharmaceutical-industry/.

${ }^{73}$ Committee on Economic, Social and Cultural Rights, Statement on the coronavirus disease (COVID-19) pandemic and economic, social and cultural right, UN Doc. E/C.12/2020/1,17 April 2020, para. 4, E/C (https://undocs.org/E/C.12/2020/1).
} 
countries, including least developed countries, countries in conflict and post-conflict situations, should be at the centre of such international endeavours." 74

The WHO, in conjunction with other international organizations, has pushed for equitable access to medicines and vaccines to combat the COVID-19 pandemic, but states' participation in such measures is not required, and some notable wealthy states such as the United States have refused to participate. In April 2020, the WHO, World Bank, Gavi, and several private sector partners, created the Access to COVID-19 Accelerator, which fosters collaboration between governments, scientists, businesses, civil society, global health organizations, and private philanthropists to accelerate the development and production of COVID-19 tests, treatments, and vaccines and promotes equitable access to these resources. ${ }^{75}$ In the same month, the UN General Assembly passed a resolution on international cooperation to ensure global access to medicines, vaccines and medical equipment to face COVID-19. ${ }^{76}$

In May 2020, numerous world leaders, diplomats, economists, and academics called upon the WHO to ensure that human rights are prioritized over corporate profit interest with respect to a COVID-19 vaccine. ${ }^{77}$ They called for an agreement to be implemented by the WHO that "[e]nsures mandatory worldwide sharing of all COVID-19 related knowledge, data and technologies"; "[e]stablishes a global and equitable rapid manufacturing and distribution plan that is fully-funded by rich nations - for the vaccine and all COVID-19 products and technologies that guarantees transparent 'at true cost-prices' and supplies according to need"; and "[g]uarantees COVID-19 vaccines, diagnostics, tests and treatments are provided free of charge to everyone, everywhere. Access needs to be prioritized first for front-line workers, the most vulnerable people, and for poor countries with the least capacity to save lives."

\section{Achieving the right to health within the human rights framework}

\footnotetext{
${ }^{74}$ Committee on Economic, Social and Cultural Rights, Statement on the coronavirus disease (COVID-19) pandemic and economic, social and cultural rights, UN Doc. (E/C.12/2020/1), para. 19.

${ }^{75}$ World Health Organization, “Access to COVID-19 Tools (ACT) Accelerator: A Global Collaboration to Accelerate the Development, Production and Equitable Access to New COVID-19 diagnostics, therapeutics and vaccines," 24 April 2020, https:/www.who.int/publications/m/item/access-to-covid-19-tools-(act)-accelerator.

76 UN General Assembly, International cooperation to ensure global access to medicines, vaccines and medical equipment to face COVID-19, UN Doc. A/RES/74/274, 21 April 2020, para. 4.

77 UNAIDS, "Uniting behind a people's vaccine against COVID-19," 14 May 2020, https://www.unaids.org/en/resources/presscentre/featurestories/2020/may/20200514_covid19-vaccine-open-letter.
} 
The important question, therefore, is how to make operational the existing legal obligations of developed countries to assist impoverished countries with the realization of the right to health, and importantly, how to coordinate the efforts of domestic governments, donor governments, and non-State actors in the realization of the right to health. As one commentator has noted, "The most glaring problem, widely debated by scholars, is whether international legal instruments and global institutions can effectively govern the diverse State and non-State actors that influence health outcomes." 78 While this remains an incredibly complex - yet particularly urgent - problem in this era of the COVID-19 pandemic, below we outline some of possible steps that the international community can take to help achieve the right to health globally, which is instrumental to the poverty reduction agenda.

As with most other economic, social and cultural rights in the ICESCR and the UDHR, the right to health is not well defined in the human rights framework and the specific obligations of governments and other actors have not been enumerated. In General Comment No. 14, the CESCR identified several core obligations of the right to health, including the obligation of developed countries to provide economic and technical assistance to developing countries. ${ }^{79}$ However, benchmarks and evaluation criteria are instrumental to encourage all governments to meet their obligations and to assess which countries need assistance and in which areas. Critically, SDG3 articulates the core elements of the right to health; the targets and indicators provide an integral framework for assessing the needs in each country, monitoring the progress of governments in the realization of the right to health, and identifying areas for developed countries to "cooperate and assist".

The CESCR actually identifies as part of a government's core obligations, the obligation to create a strategy and plan of action for the realization of the right to health that includes "methods, such as right to health indicators and benchmarks, by which progress can be closely monitored." 80 The international community, with leadership from the CESCR and the Special Rapporteur on the Right to Health, should focus attention on the annual progress across countries on the indicators of SDG3, with a special focus on the poorest countries.

\footnotetext{
${ }^{78}$ Gostin, "A Proposal for a Framework Convention," supra, note 12, 335.

${ }^{79}$ CESCR, General Comment No. 14, supra, note 35, paras. 43-45.

${ }^{80}$ CESCR, General Comment No. 14, supra, note 35, para. 43.
} 
In order for developed countries to be held accountable for their obligations under the ICESCR, there needs to be a clear articulation of the extraterritorial obligations of States (as well as clarity on the obligations of non-State actors, including multinational corporations and international financial institutions). ${ }^{81}$ With an improved and emboldened mandate, the CESCR can assume the responsibility and capacity to hold countries accountable for their obligations to provide international assistance and cooperation, with assistance from the Special Rapporteur on the right to health. The CESCR, for instance, makes Concluding Observations on the reports of States Parties to the ICESCR, and has at times commented and made recommendations to increase development assistance. Furthermore, civil society organizations submit "shadow reports," which the CESCR examines along with States Parties' reports, providing additional commentary on the States' compliance with their obligations. The CESCR has often incorporated information from these civil society reports in its recommendations. ${ }^{82}$ The mandate of the CESCR includes not only collecting these reports and making specific recommendations, but also assessing and benchmarking the compliance of developed countries with respect to their international assistance obligations. Finally, the Special Rapporteurs also make evaluations and recommendations to States Parties on the status of compliance with the obligation to cooperate and assist with the realization of the right to health.

\section{Outlines of a post-COVID-19 international financial programme to support health for all}

Finance is merely an enabler, of course, to be combined with on-the-ground systems for delivery, monitoring, and evaluation. Several such systems are being put in place, mainly as the result of progress in scaling up programmes to fight AIDS, TB, malaria, COVID-19, and other infectious diseases. The Global Fund to Fight AIDS, TB and Malaria, and the Global Alliance for Vaccines and Immunization are the two main multilateral donor funds established early in the millennium to finance the rollout of disease control efforts, and the results of these efforts have been enormously positive. The challenge of COVID-19, of course, changes the scale of the global commitment needed to achieve the targets of SDG3.

\footnotetext{
${ }^{81}$ See supra, note 72.

${ }^{82}$ Amnesty International, Holding Government to Account: A Guide to Shadow Reporting on Economic Social and Cultural Rights, 2014, http://www.ourvoiceourrights.ie/assets/files/pdf/amnesty_a_guide_to_shadow_reporting_on_escr.pdf?issuusl=ignor e.
} 
In order to prepare to achieve SDG 3 in all countries, including the poorest, by the target year 2030, we recommend five urgent priorities:

1. First, rich countries will need to scale up their overall aid to health. Our estimate is that around 0.1 per cent of donor GDP each year, roughly $\$ 50$ billion as of 2020, would be needed to close the health financing gap for the low-income countries, assuming that those countries follow through on their own domestic resource mobilization in national budgets. This estimate does not include the extraordinary costs associated with the COVID-19 pandemic, which are additional. The depression following COVID-19 creates enormous strains on health budgets and possibly an opportunity to build on the urgent investment in testing, tracing, treatment and vaccines to maintain increased investment in the health sector.

2. Second, donor countries and philanthropic foundations should properly and urgently fund the various pooled-financing mechanisms established to help low-income countries to cover the costs of responding to the COVID-19 pandemic, ${ }^{83}$ for example, to cover the costs of implementing a newly developed vaccine under the Covax program. ${ }^{84}$

3. Third, donor countries should provide targeted funding for scaling up primary health systems in order to achieve Universal Health Coverage (SDG 3.8). This can most readily be handled by expanding the responsibilities of GAVI and the Global Fund to Fight AIDS, TB, and Malaria, so that these two funds would help to cover the costs of physical infrastructure of the primary health system, training of health workers, and deployment of remunerated health workers, including Community Health Workers (CHWs).

4. Fourth, ministries of health should deploy national-scale information and communications technologies (ICTs) in order to create low-cost, state-of-the-art health delivery systems that can benefit from recent advances of ICTs. New possibilities, spurred on by the urgent need to respond to the COVID-19 pandemic, include empowering CHWs with smart-phone technologies, distance training of health workers in online courses, distance diagnostics, telemedicine, remote monitoring of patients,

83 "Funding mechanisms for COVID-19 response," prepared for the ECOSOC informal meeting of the FFD Forum on 2 June 2020. Available at:

https://www.un.org/development/desa/financing/sites/www.un.org.development.desa.financing/files/202005/Mapping\%20of\%20COVID-19\%20Response.pdf.

${ }^{84}$ For more on the COVAX program, see https://www.who.int/initiatives/act-accelerator/covax. 
emergency response systems, real-time dashboards for health informatics, medical electronic records, and more.

5. Fifth, health systems in low-income countries should begin expanding universal health coverage to include the prevention and treatment of non-communicable diseases (in line with SDG 3, Target 3.4), including cardiovascular, respiratory, metabolic, mental health, and cancers. Many of these non-communicable diseases now may be prevented or treated with relatively low-cost interventions that have become available in the past decade or so.

\section{Conclusion}

As the former Special Rapporteur on the Right to Health, Paul Hunt, said over a decade ago, "Confronted with such a complex and colossal challenge as global poverty, it is extremely important that development practitioners use all the tools available in their workshop, including the national and international human rights commitments of developing and developed states." 85 The international commitments exist in the human rights treaties, the SDGs, global conferences on financing development and the policies and programs of international financial and development institutions, but enforcement is weak and global cooperation and assistance - in line with existing commitments and obligations - are absolutely necessary to solve the global health crisis and to realize the right to health that has been affirmed by all nations for many years. It is unacceptable that the "available resources" standard of the ICESCR has resulted in substantially different standards of the right to health between developing and developed countries. It is imperative that the global community cooperate to "close the gap between developing and developed countries' highest attainable standards." 86

An economic perspective on realizing the right to health can be useful in this context, complementing the existent international obligations by identifying the most cost-effective investments for improving health systems, quantifying the financing gap to realize the right to health in poor countries, and creating benchmarks for measuring success and monitoring progress. Efforts must be scaled up. The means for success already exist. International human rights commitments call on us to make the effort. The needs are urgent, and the 2015-2030

\footnotetext{
${ }^{85}$ Paul Hunt, "Using all the Tools at Our Disposal: Poverty Reduction and the Right to the Highest Attainable Standard of Health," Development Outreach (Washington. DC: World Bank Institute, 2006) 20, http://repository.essex.ac.uk/9681/1/Hunt_proof[1].pdf.

${ }^{86}$ Alexander, "Lack of Access to HIV/AIDS Drugs," supra note 47, 13.
} 
timeframe for the SDGs offers a unique opportunity to achieve for global health what the MDGs failed to achieve and what the pandemic renders all the more urgent.

[BOX] Emergency Financing for Fighting COVID-19

In its September 11, 2020, Resolution, the UN General Assembly called for "intensified international cooperation and multilateral efforts in handling disease outbreaks, including by sharing timely, accurate and transparent information, exchanging epidemiological and clinical data, sharing materials necessary for research and development, and implementing the International Health Regulations (IHR 2005)3 and relevant guidance."87 The Resolution emphasized the importance of international cooperation to "mitigate any drawback towards achieving the Sustainable Development Goals" and highlighted the unique debt vulnerabilities of low- and middle-income countries during the pandemic. ${ }^{88}$ The UN launched a multibillion dollar coordinated global humanitarian Response Plan to fight COVID-19 in March, with additional annexes and financial appeals being added in May and July. ${ }^{89}$ As of October 23, 2020, the Response Plan was only 32.7 percent funded, with $\$ 10.3$ billion earmarked to fight the pandemic in low-income and particularly vulnerable countries. ${ }^{90}$ The Office for the Coordination of Humanitarian Affairs has been assessing the use of Country-Based Pooled Funds (CBPFs) at the field level, and as of October 23, 2020, sixteen CBPFs had provided \$226 million to COVID-19 responses. OCHA is also coordinating with State governments to prepare response plans and administer aid effectively. ${ }^{91}$ Dozens more in-country COVID-19 response programmes have been supported through the \$134 million released from the UN Central Emergency Response Fund. ${ }^{92}$ The IMF has provided emergency financing and doubled access to both its Rapid Credit Facility and Rapid Financing Instrument, allowing it to provide approximately $\$ 100$ billion in financing. ${ }^{93}$ By the end of September 2020, the IMF Executive Board had approved around \$31

\footnotetext{
${ }^{87}$ UN General Assembly, United response against global health threats: combating COVID-19, UN doc. A/RES/74/307, 11 September 2020, para. 1.

${ }^{88}$ Ibid. para. 6.

${ }^{89}$ United Nations Office for the Coordination of Humanitarian Affairs, "OCHA and COVID-19," https://www.unocha.org/covid19 (accessed October 29, 2020).

90 Ibid.

${ }^{91}$ Ibid.

92 Ibid.

${ }^{93}$ International Monetary Fund, "Factsheet: How the IMF Can Help Countries Address the Economic Impact of Coronavirus," 30 September 2020, https://www.imf.org/en/About/Factsheets/Sheets/2020/02/28/how-the-imf-canhelp-countries-address-the-economic-impact-of-coronavirus.
} 
billion in emergency funding for 76 countries and has extended flexible lines of credit to three. ${ }^{94}$ Furthermore, the IMF has provided immediate deb service relief to 29 countries through its Catastrophe Containment and Relief Trust. ${ }^{95}$ The G20 also suspended debt service on lines of bilateral credit for low-income countries. As of the end of September 2020, around sixty percent of eligible countries has already applied for this suspension. ${ }^{96}$ Most of the important interventions to support the basic obligations of developing country governments are low-cost interventions that nevertheless are not within reach of most developing countries.

94 Ibid.

95 Ibid.

96 Ibid. 